\title{
Blok atrioventrikular komplit pada anjing Pomeranian
}

\author{
Arni Diana Fitri ${ }^{1,2, *}$, Elma Nefia $^{3}$, Deni Noviana ${ }^{1,4}$ \\ ${ }^{1}$ Rumah Sakit Hewan Pendidikan, Fakultas Kedokteran Hewan, Institut Pertanian Bogor \\ ${ }^{2}$ Program Studi Ilmu Biomedis Hewan, Sekolah Pasca Sarjana, Fakultas Kedokteran Hewan, Institut Pertanian Bogor \\ ${ }^{3}$ March Animal Clinic Jakarta \\ ${ }^{4}$ Divisi Bedah dan Radiologi, Departemen Klinik Reproduksi dan Patologi, Fakultas Kedokteran Hewan, Institut Pertanian Bogor
}

\begin{abstract}
ABSTRAK: Blok atrioventrikular komplit (AV blok III) merupakan kelainan jantung yang disebabkan oleh blok hampir semua impuls listrik jantung pada $A V$ junction ditandai dengan ketidaksamaan denyut di atrium dan ventrikel. Tulisan ini melaporkan kasus pada pasien yang dirujuk ke Rumah Sakit Hewan Pendidikan Fakultas Kedokteran Hewan Institut Pertanian Bogor. Anjing Pomeranian betina, usia 3 tahun, bobot badan 1,53 kg dirujuk dengan keluhan pembesaran jantung untuk dilakukan ekhokardiografi di cardiology center service. Pemeriksaan lain yang dilakukan adalah pemeriksaan fisik, radiagrafi thoraks dan elektrokardiograf (EKG) serta ekhokardiografi. Pemeriksaan fisik menunjukkan hewan kurus dengan body condition score $3 / 9$, lemah, suhu $39,4^{\circ} \mathrm{C}$, freksuensi nafas $99 \mathrm{kali} /$ menit, frekuensi jantung $84 \mathrm{kali} / \mathrm{menit}$. Pemeriksaan EKG menunjukkan jantung hewan mengalami AV blok III ditandai dengan beberapa gelombang P tidak muncul, gelombang Q dan gelombang R terlalu tinggi serta gelompang $\mathrm{T}$ abnormal. Radiografi thoraks menunjukkan adanya kardiomegali dan ekhocardiografi menunjukkan detak jantung irregular, otot jantung menebal, ejection time 0,18 detik, fractional shortening $45 \%$, ejection fraction $83 \%$ dan perbandingan diameter aorta dan lumen atrium 2:1. Pemeriksaan color Doppler terlihat adanya turbulensi aliran darah pada katup atrioventrikular dan katup semilunar.
\end{abstract}

Kata kunci:

jantung, blok atrioventrikular komplit, elektrokardiografi, radiografi, ekhokardiografi.

\section{- PENDAHULUAN}

Anjing dengan kasus blok atrial umumnya mengalami hipertropi ventrikular. Kejadian blok atrial kemungkinan karena kelebihan volume isi jantung yang disebabkan oleh bradikardia yang sudah lama terjadi. Tingkat insiden terjadinya kematian mendadak cukup besar pada pasien hipertropi miokardial (Vos et al. 1998). Catatan medis di Rumah Sakit Hewan Pendidikan (RSHP) Fakultas Kedokteran Hewan, Institut Pertanian Bogor (FKH IPB) terdapat lebih dari 100 kasus jantung periode 10 tahun terakhir (Amalia 2019).

Blok atrioventricular komplit (AV blok III), merupakan kelainan jantung yang disebabkan adanya blok hampir semua impuls listrik pada $A V$ junction dan ditandai dengan ketidaksamaan denyut atrium dan ventrikel. Kasus ini terjadi karena keterlambatan pelepasan ritme ventrikel yang menghasilkan rendahnya curah jantung dan menyebabkan kegagalan jantung (Burtnick 20110). Studi ini melaporkan kasus pasien rujukan yang ditangani di RSHP FKH IPB.

\section{- KASUS}

Anamnesis: Pasien dirujuk oleh klinik swasta di Jakarta ke RSHP FKH IPB dengan keluhan pembesaran jantung untuk pemeriksaan ekhokardiografi di cardiology center service. Sinyalemen: anjing Pomeranian betina, usia 3 tahun, bobot badan 1,53 kg. Pemeriksaan fisik: hewan kurus, body con- dition score $3 / 9$, lemah secara umum, suhu $39,4^{\circ} \mathrm{C}$, frekuensi nafas $99 \mathrm{kali} / \mathrm{menit}$, frekuensi jantung $84 \mathrm{kali} /$ menit. Pemeriksaan penunjang: elektrokardiografi (EKG), radiografi dan ekhokardiografi.

\section{- HASIL}

Pemeriksaan EKG terjadi AV blok III ditandai tidak adanya gelombang P sesekali pada kompleks gelombang, perpanjangan interval QT, gelombang Q dan R terlalu tinggi (puncak tidak seragam), gelombang $\mathrm{T}$ abnormal serta gelombang QRS komplek tampil tidak seragam (Gambar 1A dan Tabel 1). Hasil radiografi regio thoraks terlihat bayangan jantung membesar (kardiomegali) (Gambar 1B).

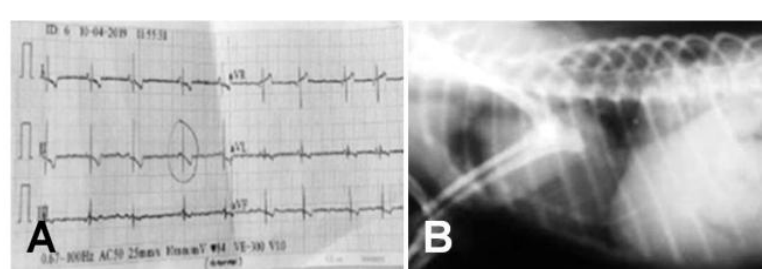

Gambar 1 Pemeriksaan penunjang EKG (A) dan radiografi (B).

Citra ekhokardiografi terlihat penebalan otot jantung, kelainan struktur katup jantung, serta kontraksi tidak teratur

Diterima: 05-01-2020 | Direvisi: 28-01-2020 | Disetujui: 02-02-2020 (C) 2020 CC-BY-SA. Ini adalah artikel Open Access yang didistribusikan berdasarkan ketentuan dari Creative Commons Attribution ShareAlike 4.0 International License (https://creativecommons.org/licenses/by-sa/4.0/). 
(Gambar 2 dan Tabel 2-4).

Tabel 1. Hasil pemeriksaan EKG

\begin{tabular}{|c|c|}
\hline Aspek & Nilai \\
\hline Frekuensi (min) & 84 \\
Irama & irregular \\
Aksis (derajat) & 57 \\
Tinggi gelombang P (mV) & 0,10 \\
Lebar gelombang P (detik) & 0,02 \\
Interval P- R (detik) & 0,08 \\
Interval Q-T (detik) & 0,32 \\
Kompleks QRS (detik x mV) & $0,02 \times 1,2$ \\
\hline
\end{tabular}

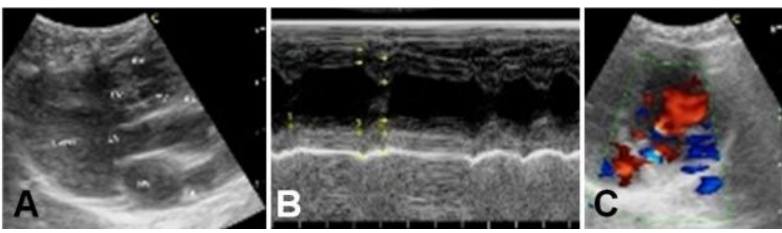

Gambar 2 Ekhokradiogram jantung. (A) brightness-mode, (B) motion-mode, dan (C) Color flow Doppler-mode.

Table 2 Ekhokardiografi brightness-mode

\begin{tabular}{|c|c|}
\hline Parameter & Hasil \\
\hline Ritme jantung & Irregular \\
Endocardium & Menebal \\
Struktur katup & Corda tendine abnormal \\
Pergerakan katup & Tidak teratur \\
\hline
\end{tabular}

Tabel 3 Ekhokardiografi motion-mode

\begin{tabular}{|c|c|c|}
\hline Parameter & Hasil & Rentang Normal \\
\hline HR (bpm) & 89 & $60-240$ \\
IVSTd (mm) & 3,5 & $2,2-4,0$ \\
LVIDd (mm) & 18,9 & $1,20-1,98$ \\
LVPWd (mm) & 6,3 & - \\
IVSTs (mm) & 6,5 & $5,3-5,9$ \\
LVIDs (mm) & 10,4 & $0,52-1,08$ \\
LVPWs (mm) & 8,5 & $5,4-6,0$ \\
ET (detik) & 0,18 & $0,15-0,35$ \\
EDV (ml) & 6,72 & - \\
ESV (ml) & 1,11 & - \\
SV (ml) & 5,61 & - \\
CO (1/menit) & 0,5 & - \\
EF (\%) & 83 & $55-85$ \\
FS (\%) & 45 & $0,39-0,61$ \\
LAAs (mm) & 4,6 & $0,93-1,51$ \\
AoDd (mm) & 9,6 & $0,72-1,19$ \\
LAAs:AoDs & $1: 2$ & $1: 1$ \\
\hline
\end{tabular}

Tabel 4 Ekhokardiografi color flow Doppler-mode

\begin{tabular}{|c|c|}
\hline Parameter & Hasil \\
\hline Katup Atrioventrikular & Turbulensi warna \\
Katup Semilunar & Turbulensi warna \\
\hline
\end{tabular}

\section{- PEMBAAHASAN}

Otot jantung yang tebal (hypertrophy) menyulitkan jantung memompa darah, baik keseluruh tubuh maupun ke jantung sendiri (Lou et al. 2018). Kondisi ini sering tidak terdiagnosa (Sato et al. 2018). Endokardiosis (AV valve endocardiosis) merupakan penyakit degenerasi myxomatous progresif dari katup atrioventrikel dan dapat terjadi pada semua breed (Ghiassi 2019). Perkembangan penyakit dimulai dengan fraksi regurgitasi kecil dari ventrikel ke atrium yang dengan mudah diterima oleh atrium dan volume stroke dipertahankan. Fraksi regurgitan dari total volume stroke ventrikel kiri meningkat seiring perkembangan penyakit. Ventrikel kiri mengkompensasi dengan meningkatkan volume diastolik akhir (preload) dan meningkatkan denyut jantung terus menerus. Peningkatan preload menyebabkan peningkatan kekuatan kontraksi ventrikel kiri (Ghiassi 2019).

Perawatan umum adalah pemberian diuretik seperti furosemide dan penghambat enzim pengonversi angiotensin (ACE) ketika pasien mengalami gagal jantung. Sediaan ACE inhibitor dapat diberikan sebelum gagal jantung untuk meningkatkan prognosis (Sasaki et al. 2018). Kasus gagal jantung parah atau berulang dapat diberikan diuretik dengan efek pada nefron bagian distal, inotropik positif, dan pengurang after load lainnya. Obat glikosida jantung dianjurkan untuk perbaikan kontraktilitas, tonus vagal, dan aktivitas baro reseptor. $\beta$-blocker atau calcium channel blockers dapat ditambahkan dalam kasus takikardia yang refrakter terhadap digoxin (Annikov et al. 2019).

\section{- SIMPULAN}

Kasus AV blok III pada anjing dengan hipertrofi kardiomiopati dan $A V$ valve endocardiosis tidak terlihat pada pemeriksaan fisik dapat didiagnosa dengan kombinasi EKG, radiografi, dan ekhokardiografi.

\section{- INFORMASI PENULIS}

Penulis untuk Korespondensi

*ADF: arnidianafitri@gmail.com; arnidianafitri@yahoo.com Rumah Sakit Hewan Pendidikan, Fakultas Kedokteran Hewan, Institut Pertanian Bogor. Jln. Agatis Kampus IPB Dramaga, Bogor.

\section{- UCAPAN TERIMA KASIH}

Terima kasih kepada PT MUM atas penyediaan alat ultrasonografi di RSHP FKH IPB sebagai diagnosa penunjang. Terimakasih juga kolega dokter hewan dan pegawai yang terlibat pengambilan data.

\section{- PUSTAKA ACUAN}

Amalia CA. 2019. Kasus Kelainan Jantung Anjing secara Ultrasonografi di Rumah Sakit Hewan Pendidikan dan Klinik Hewan Tahun 2013-2018. [Skripsi]. Bogor: Institut Pertanian Bogor.

Annikov VV, Mikhalkin AS, Annikova LV, Yegunova AV. 2019. Evaluation of an echocardiogram in the preclinical stage of valve endocardiosis in dogs using an angiotensin converting enzyme inhibitor and an aldosterone antagonist. International Journal of Research in Pharmaceutical Sciences. 10(4): 2907-2913.

Burtnick LP. 2011. The 5-minute Veterinary Consult. UK: Wiley. Ghiassi SR. 2019. Myxomatous mitral valve disease in dogs, 37 cases (2010-2015). EC Veterinary Science. 4: 473-481.

Luo Y, Xu Y, Liang C, Xing W, Zhang T. 2018. The mechanism of myocardial hypertrophy regulated by the interaction between mhrt and myocardin. Cellular Signalling. 43(1): 11-20.

Sasaki T, Kimura Y, Imai T, Machida N. 2018. Complete atrioventricular block due to primary cardiac lymphoma in a dog. Japanese Journal of Veterinary Research. 66(4): 305-310.

Sato Y, Kawasaki T, Honda S, Harimoto K, Miki S, Kamitani T, Shiraishi H, Matoba S. 2018. Third and fourth heart sounds and myocardial fibrosis in hypertrophic cardiomyopathy. Circulation Journal. 82(2): 509-516.

Vos MA, De Groot SH, Verduyn SC, Van der Zande J, Leunissen HD, Cleutjens JP, Van Bilsen M, Daemen MJ, Schreuder JJ, Allessie MA, Wellens HJ. 1998. Enhanced susceptibility for acquired torsade de pointes arrhythmias in the dog with chronic, complete AV block is related to cardiac hypertrophy and electrical remodeling. Circulation. 98(11): 1125-1135. 